\title{
A conceptual framework in promoting knowledge management in electricity industry in South Africa: The case of ESKOM
}

\author{
Akhabue A. Okharedia \\ Graduate School of Business Leadership, \\ University of South Africa
}

\section{Keyword}

Knowledge management, organization performance, electricity industry, South Africa

\begin{abstract}
This research paper attempts to investigate if the implementation of knowledge management capability, adaptive strategy for managing knowledge and the minimisation of knowledge management challenges can help ESKOM to improve its organizational performance. In investigating the above issues, we used quantitative research methodology to collect and analyse the research data. The findings of the research confirm that it is imperative for ESKOM to pay urgent attention on how best the organization can improve on its knowledge management capability, adaptive strategy for managing knowledge and a mechanism to be used in minimizing the current knowledge management challenges confronting ESKOM. In view of the research findings, we developed a conceptual framework that ESKOM needs to implement to improve its organization performance in respect of customer satisfaction, employee's retention, attraction and the quality of the services it renders to the public.
\end{abstract}

Corresponding author: A.A. Okharedia

Email addresses for the corresponding author: aaokharedia@gmail.com

First submission received: $23^{\text {rd }}$ August 2017

Revised submission received: $14^{\text {th }}$ January 2019

Accepted: $7^{\text {th }}$ February 2019

\section{Introduction}

\subsection{Historical Background of Eskom in South Africa}

In South Africa, historical records show that the first electric power plants were developed over a century ago to support the mining industry. Most mines used on-site electrical generators until 1909, when the Victoria Falls Power Company was established. In 1923, the present electricity industry (Eskom) began to provide electricity for the country's railroads and non-mining industries. Eskom bought out the Victoria Falls Power Company in 1948 and has been the country's major power producer in South Africa.

The company's sales increased faster than the country's GDP growth after World War II, and the company expanded steadily. From 1950 to 1982, sales grew at an average rate of $8 \%$ a year until the early 1990's when Eskom supplied more than 97\% of the electricity used nationwide. A few mines and industries had their own power generators. Eskom has 26 power station in commission with nominal capacity of more than 42, 000 megawatts and a total network of 359854 kilometres of power lines, serviced by approximately 32600 employees. It supplies $95 \%$ of South Africa's electricity and almost half of the electricity generated on African continent. In the past years, the continual provision of reliable and affordable electricity has been its task, and this has ensured stability and growth of the South African economy. This in turn contributes to investor confidence and addresses the overall challenge of poverty alleviation and sustainable development in South Africa. For many years in the past, Eskom operated in an environment of surplus capacity.

As South African consumer demand increased, however, this surplus was depleted. Eskom's capacity expansion programme acknowledges the current challenges facing South Africa which need to be addressed.

Eskom has accelerated the rollout of its build programme to ensure that South Africa has enough generation and transmission capacity to supply the future energy needs of the country. Eskom will spend R150 billion over the next five years to upgrade South Africa's electricity infrastructure; currently Eskom has more than 11000 megawatts in the implementation phase of its life cycle model. 
However, the current challenges facing Eskom include the following: (1) Quality of its service, (2) Continuity of supply of electricity (3) Financial sustainability (4) Public confidence in Eskom (5) Restructuring of electricity distribution system (6) The current load shedding issues.

In 2007, things went wrong in Eskom, there was a technical failure, and this resulted in power shortage which was managed by means of rotational load shedding. In January 2008, the situation was aggravated by prolonged torrential rainfall which flooded open cast coal mines and slowed coal delivery to power stations.

In addition to this was lack of expert skills and good management of the human resources available in the company. In view of this, the once invincible national utility was shaken to its core and this raised many questions about the planning, knowledge management and operational competence of Eskom.

Considering the above questions raised this paper attempts to examine the issue of knowledge management and how this affects Eskom operational performance.

\section{The concept of knowledge management and its problem of definition}

Historically, the concept of knowledge management emerged from three different continents in different ways. In Europe the principal focus of knowledge management (KM) was on measuring intangibles and intangibles accounting. In Japan the focus was on creating new knowledge while in USA the focus was on exploiting existing knowledge and information using information systems. However, at a later stage, the three concepts merged together to give rise to what we now referred to as knowledge management.

Unfortunately, as time passed, the USA model became more prominent and eventually over shadow the very spirit of KM. In recent time, an attempt is been made to claim that KM belong to data management, information systems, record management, human resource management, economics, operations management and other functional areas. However, the concept of KM has been diminished and this has its own consequences and implication in understanding the concept.

\subsection{Implications}

The current fight of ownership of the concept among various functional areas has created confusion among adopters of the concept in the market place, academics and practitioners.

The confusion and misinformation created around the concept has made it look more complex and complicated. By focusing on and bringing it into functional area like IT, the concept is forced to underperform. It is used more as a risk minimization strategy. For example, KM is used to codify as much tacit knowledge as possible and document it into explicit form so that, if the concerned employee leaves the company some part of his knowledge remains with the company (Rajesh K. Pillania: 2009).

The above implications notwithstanding, the concept of KM if used in the true perspective, it can lead to sustainable competitive advantages and help in the development of electricity industry. However, before we examine how KM has helped in the development of infrastructure electricity in South Africa, it is perhaps necessary for us to briefly highlight the strategic framework associated with knowledge management.

Earl (2001) has classified this framework into seven schools which will be discussed briefly, and we must also bear in mind that the various schools as he has classified them are not mutually exclusive so that an organization can use these strategies simultaneously.

The first school he highlighted is the system school strategies which aim to capture and store the knowledge repositories. This logically implies that the fundamental concerns of system school are the creation and codification of knowledge (Hansen et al, 1999; Nonaka et al; 2000; Wickra Masinghe, 2007)

The second school is the cartographic school strategies which focus on mapping knowledge by creating yellow pages or directories of knowledge owners. When people need certain kinds of knowledge, they look in the yellow pages to find who has the knowledge needed and how this person can be reached.

The third school is the process school strategies which aim to provide people not only with the knowledge they request but also with the most useful knowledge that is relevant to their current tasks. (EL-Korany, 2007, Grant, 1996; Kim et al, 2003) 
The fourth school is the commercial strategies which support the concept of managing knowledge as an asset and stress the importance of organization's capability in recognizing the economic value of their knowledge (Davenport et al; 1998, Gold et al. 2001, Kim's 1997). This has been used in Japan to develop their infrastructures.

The fifth school is the organizational strategies which aim to facilitate knowledge management activities by designing organizational structures or inter-organizational networks that connect knowledge owners for sharing knowledge (Mei et al. 2004; Phusavat and Kess, 2008)

The sixth school is the spatial strategies which take advantage of the "use of space" to facilitate knowledge exchange. This strategy intends to facilitate knowledge exchange by encouraging socialization through proper use of space and it also promote the spirit of face to face contact which will help to transfer knowledge directly.

All the above strategies have been found as a key knowledge management resources that can be useful in not only the development of infrastructure of a company but also as a resource in resolving crisis in management.

Furthermore, the above strategies also systematically incorporate $\mathrm{KM}$ initiatives that allow companies or organizations to choose the best KM approaches in achieving their goals and objectives.

\section{The Problem Statement of this Research}

In South Africa, the electricity industry (ESKOM) is currently facing difficulties in supplying electricity to meet consumers demand. The failure to meet the current demand has led to load shedding and this has made the supply of electricity to be erratic and unreliable. In 2007, there was a general dictum among the public that the technical failure in ESKOM is responsible in power shortage while in 2008, the situation was aggravated by prolong torrential rainfall, which flooded open cast coal miners, and this slowed coal delivery to power stations.

In addition to the above, other factors that have been attributed to the failure of ESKOM include among others lack expert skills, good management of human resources available in ESKOM, lack of planning knowledge management capability, lack of adaptive strategy for managing knowledge and operational incompetency of ESKOM.

Considering the above issues, this research paper attempts to examine and develop a conceptual framework that would promote knowledge management for ESKOM to achieve a better organisational performance.

Fig 1: Proposed Conceptual Framework to be Investigated in Respect of

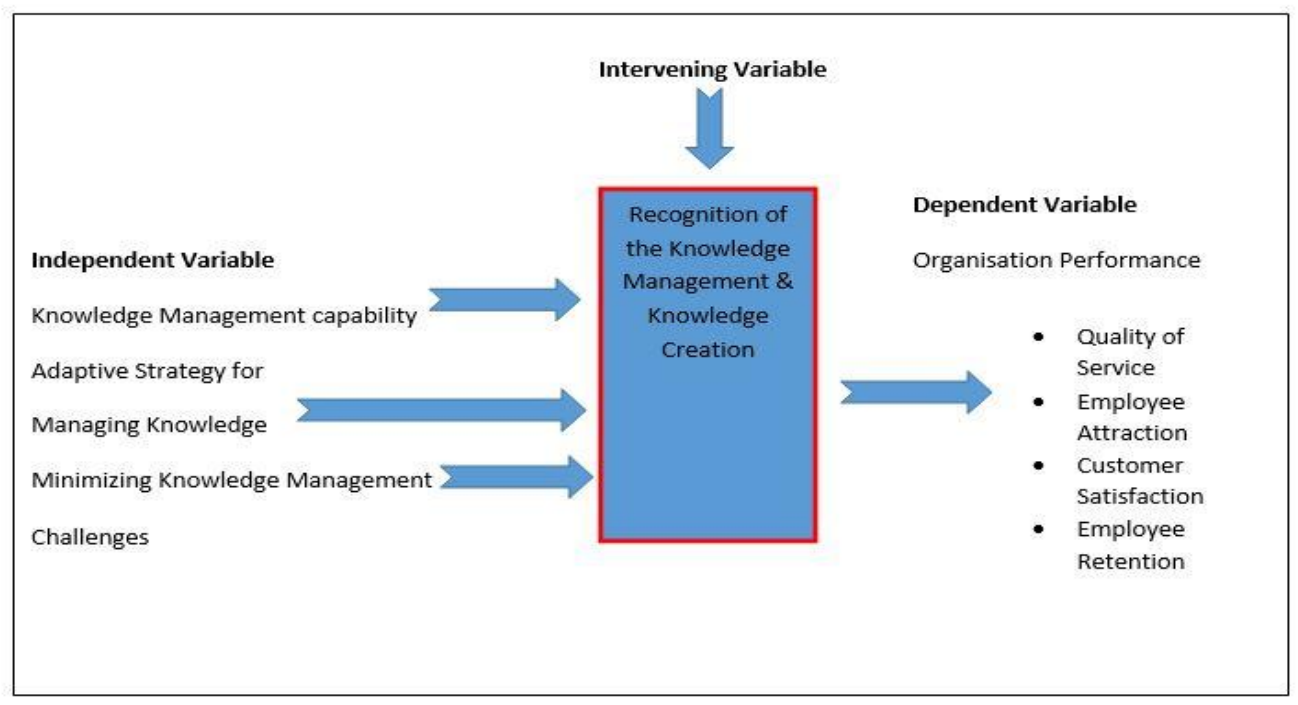




\subsection{The Rationale for the Study}

The purpose of this research is to investigate the research problem identified above and to recommend to ESKOM the possible strategy to be adopted to improve its performance and meet the demand of the consumers at minimum cost.

The research work of Zenona Atkociuniene (2016:11) confirms that the main goal of knowledge management in business organizations is to transform knowledge into capital, thus maximising organisational efficiency. He argued further that continuous knowledge creation and its use undoubtedly increase an organisations value in the market. In addition to this, organisation structure must strive to be flexible and able to change in response to the external and internal environments. He strongly believes that consistent strategic management, adaptive to changes in the environment, organisational learning, and proper knowledge management with other factors should ensure the competitive advantage of the organisational structure. He finally submitted in his research findings that it is only organisations that systematically create and diffuse, update and apply knowledge to improve their products or services in a continuous pattern that can be successful in achieving their goals.

Based on their above premises, this research paper attempts to examine how the independent variables in Fig1 coupled with the influence of the possible intervening variable can help ESKOM as a business organization to achieve better performance of its services in respect of the supply of electricity in South Africa.

\subsection{Objectives of the study}

- To investigate and analyse how the implementation of knowledge management capability can promote organization performance.

- To investigate and analyse how adaptive strategy for managing knowledge can enhance organization performance.

- To investigate and analyse how the propensity to minimize knowledge management challenges can enhance organization performance.

- To investigate the influence of possible intervening variables like the desire to create related knowledge, transfer of related knowledge, integration of related knowledge can help in enhancing organizational performance

\subsection{Research Questions}

In what ways do you think knowledge management capability can influence organizational performance in respect of quality of service, customer satisfaction, employee retention and attraction.

To what extent do you think adaptive strategy for managing knowledge can influence organizational performance in terms of quality of service, customer satisfaction, employee retention and attraction.

What are the best ways in which the challenges affecting knowledge management in business organization can be minimized to enhance performance in respect of quality of service, customer satisfaction, employee retention and attraction?

To what extent do you think the desire to create related knowledge, the transfer of related knowledge and integration of related knowledge can enhance the performance of your organization. What are the challenges facing Knowledge Management in your business organization?

\section{Theoretical consideration and Literature Review}

In the academic circles, various attempts have been made to use theoretical underpinning to explain the concept of knowledge management. In view of this, an attempt will be made in this paper to take a critique of two relevant theories that have direct bearing with this research. The first theory to be considered in this paper is the intellectual property theory, which highlights the need to account for knowledge and the need for 'due care' in managing it. This theory encompasses ethical issues, patents, trade secrets and other proprietary rights (slater 1998). There are few techniques for assigning monetary value to organizational knowledge (Bohn: 1994). There is also concern that poor knowledge management poses dramatic, yet unaccounted risks to organizations (Marshall et.al, 1996). Hence, these essential accounting needs, plus quality - driven management, motivates the need to measure organizational knowledge and management. 
In the case of ESKOM, it enjoys patent and proprietary rights, as a state monopoly and yet it is not performing to capacity as expected of the industry. In view of this poor performance of ESKOM, despite the proprietary rights in respect to state monopoly an attempt will be made to examine to what extent ESKOM is paying attention to the issue of knowledge management to enhance its performance.

The second theory is the knowledge economy theory, and this is an important extension to information economics. It essentially regards the 'product life cycle' of knowledge, applying this to either internal market within an organization or the external market place, a commercial market for managing knowledge economy within an organization is important because professional knowledge is a valuable commodity. This theory is of the view that there are several important management decisions that are directly informed by the knowledge economics rationale. One decision, for example, is determining how and when to develop professional knowledge internally and under what circumstances it is more attractive to use external experts. Another decision is how internal knowledge should be considered with external knowledge. Furthermore, there is a decision regarding both how and when external knowledge should be used. Consulting firms are more interested in the knowledge economy, since their product is developed and marketed where their tasks are given to them. In addition to the above, the knowledge economy theory also describes the need for professional support in organizations. The basic functions of professional support include communication with the environment, reduction of complexity and risk coordination of the routines.

Professional or commercial knowledge is necessarily characterised by heuristics based on four elements. These elements are universal, scientific knowledge, routinized skill based on deep practical experience, judgement for optimizing the further use of experts and capacity for decomposing a unique complex task into a set of routine, simple tasks (Tordoir:1955). In summary, this theory deals with knowledge economy and this revolves around how organizations can enjoy both internal and external markets to increase their performance.

Eskom as a state monopoly already enjoys both internal and external markets since there is no visible competition in terms of supply of electricity in South Africa. Unfortunately, the fruitfulness in South Africa does not enhance the profitability and survival of the organization. The two theoretical issues discussed above have not enhanced the performance of Eskom as a state monopoly and in view of this, there is an urgent need to look at the internal issues like knowledge management of the organization and asses how it can be used to promote Eskom performance. Past empirical studies have also highlighted the importance of knowledge management in enhancing organizational performance. For example, the work of Zenona Atko (Iuniene (2016:111), reveal the importance of knowledge management as well as its application and its influence on organizational efficiency. He is of the view that only the organisational structures that systematically create and diffuse, update and apply knowledge to the development of new technologies and products/services, i.e., those that are engaged in continuous innovation are those that can be successful in achieving their goals. He is also of the view that company seeks competitive advantage in the market by relying more on the knowledge and experience of its employees rather than on the use of the possibilities offered by information technologies.

Other empirical studies have fully reflected that KM approach has deep roots in implicit KM (Sielof: 1999; Matzkin:2008). Studies have suggested that organisations at the early stages of KM adoption should reinforce their KM related practices before they formally adopt KM. This has been proven as valuable in the case of Hewlett - Packand (Sieloff: 1999); Aprona (Cruz et al: 2009) and Tata Consulting Services (Sharma et al: 2007).

\subsection{Research Hypotheses}

From the above discussion and the literature review, we now derived the following hypotheses which will be tested in this research.

Hypothesis 1

There is a positive relationship between knowledge Management capability and organizational performance.

Hypothesis 2

There is a positive relationship between Adaptive Strategy for managing knowledge and organizational performance 
Hypothesis 3

There is a positive between minimizing knowledge Management Challenges and organizational performances

\section{Research Methodology}

To investigate and analyse the above hypotheses in respect of knowledge management and organizational performances, we used quantitative research techniques. In respect of this quantitative technique, we used structured questionnaire to solicit for the necessary information. We asked both closed and open-ended questions. The rationale for the open-ended questions was to allow the respondents to fully express their views on the question asked and give more information on the specific question.

The questionnaire was administered via e-mail to the selected respondents (systematic sampling) within the various units of the organization and those respondents from outside the organization were also included in the study. The outside respondents include academic experts who lecture in the field of knowledge management and has also published in the area. The second outside respondents included in the study are members of the KM Practitioners Group who meets regularly to exchange ideas and engage in $\mathrm{KM}$ discussions.

\subsection{Population for the study}

This study finally consists of 140 respondents out of the 160 respondents we had earlier considered. Eskom staff from the various departments, namely; (a) Finance Dept, Human Resource Dept, production Dept and Marketing Dept consist of 100 respondents while the academic experts and the KM Practitioners are 40 in number. All the respondents were selected through a systematic sampling technique. (Probability sampling) from the larger population. The systematic sampling technique has the advantage of given each respondent equal chances of being selected among the group. This to a great extent minimized the element of biasness in the selection of the respondents.

However, one of the problems with mail surveys is the low response rate of between 15 percent and 25 percent (Struwig and Stead: 2001). At these response rate we were able to receive only 140 respondents in total, this is out of the 160 respondents we had earlier identified and selected through a systematic sampling technique.

In the data analysis, we used the chi-square and the Pearson's contingency coefficient $(\mathrm{C})$ to test the hypotheses.

To validate this study, we used relevant respondents who have a good knowledge of the concept of knowledge management and its implementation. For us to improve the accuracy and truthfulness of the scientific findings, we used a systematic sampling technique to select those respondents. According to Knupfer and McLellan (2017), they argued that a valid study should demonstrate what exists and is accurate, and a valid instrument or measure should measure what it is supposed to measure. To validate our research instrument (Questionnaire) we sought the approval of the questionnaire from specialists in the field of knowledge management before the pilot test and the final questionnaire were administered to all the respondents. In terms of the reliability of the instrument used, we assumed that repeated measures of a phenomenon using objective methods establish the truth of the findings. Punch (2013) stated that "The more times the findings of a study can be replicated, the more stable or reliable the phenomenon is thought to be". In other words, it is the idea of replicability, repeatability and stability of results or observation.

To meet the above conditions, standardised questionnaire was used quantitatively to collect the data to improve the replicability, repeatability and the reliability of the result. To achieve a reliable result in the data analysis, we used the chi-square and the Pearson's contingency coefficients (C) to test the hypotheses which can also be used in similar studies in future. The application of this statistical techniques quantitatively renders the research findings more reliable 


\section{Data analysis and discussion}

\begin{tabular}{|l|l|l|l|}
\hline Nature of Response & $\begin{array}{l}\text { Yes, knowledge Management } \\
\text { capability has a positive } \\
\text { relationship with organizational } \\
\text { performance }\end{array}$ & $\begin{array}{l}\text { No, knowledge Management } \\
\text { capability has no positive relationship } \\
\text { with organizational performance }\end{array}$ & Total \\
\hline Respondents & $\begin{array}{l}(20.4) \\
\text { Finance Department }\end{array}$ & $\begin{array}{l}5 \\
(5.6)\end{array}$ & 25 \\
\hline Human Resource Dept & $\begin{array}{l}22 \\
(20.4)\end{array}$ & $\begin{array}{l}3 \\
(4.6)\end{array}$ & 25 \\
\hline Production Department & $\begin{array}{l}19 \\
(20.4)\end{array}$ & $\begin{array}{l}6 \\
(4.6)\end{array}$ & 25 \\
\hline Marketing Department & 20 & 5 & 25 \\
\hline $\begin{array}{l}\text { Members KM } \\
\text { Practitioners }\end{array}$ & $\begin{array}{l}(20.4) \\
(16.3)\end{array}$ & $\begin{array}{l}3 \\
(3.7)\end{array}$ & 20 \\
\hline $\begin{array}{l}\text { Academic Experts on } \\
\text { knowledge management }\end{array}$ & 16 & 4 & 20 \\
\hline Total & $116.3)$ & $(3.7)$ & 140 \\
\hline
\end{tabular}

The first hypothesis deals with the relationship between knowledge management capability and organizational performance.

$\mathrm{Ho}^{\mathrm{H}}$ : There is no positive relationship between knowledge management capability and organizational performance.

$H_{1}$ : There is a relationship between knowledge management capability and organizational performance

Observed $X^{2}=2.50$

$\mathrm{Df}=5$

Critical value at 0.95 level of significance $=1.45$ and since the observed $\mathrm{X} 2$ is greater than the critical value, we reject the $\mathrm{H} 0$ hypothesis and accept the $\mathrm{H} 1$. This therefore shows that there is a positive relationship between knowledge management capability and organizational performance.

To find out if it is a strong relationship, we used the Pearson's contingency coefficient (C).

$$
\mathrm{C}=\sqrt[X^{2}]{X^{2}+\mathrm{N}}=0.11
$$

Since ' $\mathrm{C}$ ' is not negative, this therefore shows the relationship is strong and not weak.

This finding shows there is a need for Eskom to work on its knowledge management capability in respect of how to improve its efficiency if the industry is to meet the demands of the consumers. Other past empirical studies also indicate that there is a strong positive relationship between knowledge management capability and organizational performance. For example, the work of Zack (1996) argues that there are four elements of knowledge management capability namely, knowledge acquisition, refinement, storage and retrievals. All those elements must be well organized for the organisation to perform well.

Gold et al (2001) argues that organizations must possess two basic abilities to manage knowledge, namely knowledge infrastructure capability and knowledge process capability. The former is concerned 
with technology, organizational structure, and corporate culture, the latter is concerned with knowledge acquisition, conversion and application processes. Tiwana (2002) in his studies on knowledge management capability (KMCs) include finding, creating something new, packaging, assembling, reusing and revalidating knowledge. Tanriverdi (2005) purposes a multi-business firm concept, which divides knowledge management capability into two categories: KM within and KM across business units. Cepeds and Vera (2007) suggested different categories of KMC, namely; knowledge retention and knowledge utilisation.

However, from our research findings and the review of past studies on knowledge management capability that is highlighted above, our submission here is that every knowledge managing capability must go through the three-step process of

Creation of related knowledge

Transfer of related knowledge

Integration of related knowledge

The above three step - process is regarded in this research as the intervening variables. This is fully illustrated in the conceptual framework we intend to recommend to Eskom.

The second hypothesis deals with the analysis of understanding the relationship between adaptive strategy and organizational performances.

Hypothesis 2

H0: There is no positive relationship between adaptive strategy for managing knowledge and organizational performance.

H1: There is a positive relationship between adaptive strategy for managing knowledge and organizational performance.

\begin{tabular}{|c|c|c|c|}
\hline \multicolumn{4}{|l|}{ NATURE OF RESPONSE } \\
\hline Respondents & $\begin{array}{l}\text { Yes, adaptive strategy in knowledge } \\
\text { management has a positive } \\
\text { relationship with organizational } \\
\text { performance. }\end{array}$ & $\begin{array}{l}\text { No, adaptive strategy in } \\
\text { knowledge management has } \\
\text { no relationship with } \\
\text { organizational performance }\end{array}$ & Total \\
\hline Finance Department & $\begin{array}{l}24 \\
(20.8)\end{array}$ & $\begin{array}{ll}+1 \\
(4.1)\end{array}$ & 25 \\
\hline Human Resource Dept & $\begin{array}{l}21 \\
(20.8)\end{array}$ & $\begin{array}{l}4 \\
(4.1)\end{array}$ & 25 \\
\hline Production Department & $\begin{array}{l}18 \\
(20.8)\end{array}$ & $\begin{array}{l}7 \\
(4.1)\end{array}$ & \\
\hline Marketing Department & $\begin{array}{l}19 \\
(16.7)\end{array}$ & $\begin{array}{l}6 \\
(3.2)\end{array}$ & \\
\hline $\begin{array}{l}\text { Members of KM } \\
\text { Practitioners }\end{array}$ & $\begin{array}{l}18 \\
(16.7)\end{array}$ & $\begin{array}{l}02 \\
(3.2)\end{array}$ & \\
\hline \multirow[t]{2}{*}{ Academic Experts on KM } & $\begin{array}{l}17 \\
(16.7)\end{array}$ & $\begin{array}{l}03 \\
(3.2)\end{array}$ & \\
\hline & 117 & 23 & 140 \\
\hline
\end{tabular}

Observed $\mathrm{X} 2=6.53$

$\mathrm{DF}=5$

Critical value at 0.95 level of significance $=1.145$ since the observed $\mathrm{X} 2$ is greater than the critical value, we reject the $\mathrm{H} 0$ hypothesis and accept the $\mathrm{H} 1$. This therefore shows that there is a positive relationship between adaptive strategy in knowledge management and organisational performance. To find out if it is a strong relationship, we used the Pearson's contingency coefficient (C) 


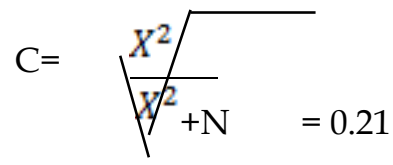

Since ' $C$ ' is not negative, this shows that the relationship is strong and not weak.

This finding confirms that there is a need for ESKOM to work on its adaptive strategy document if the organization is to perform to the standards expected of it by members of the public. There is an urgent need for ESKOM to revisit and amend its present strategy document. Some studies on KM have earlier indicated the importance of adaptive strategy in the implementation of KM. Adaptive strategies are sometimes put in place to give meaning and significance to KM practices for creating, assimilating, disseminating and protecting knowledge (Alevi and Leidner, 1999; Massey et.al. 2002).

It has been argued in academic circles that adaptive strategic knowledge management helps organizations to adapt easily to new challenges and create the spirit of innovativeness and creativity. Considering this argument, Eskom needs to develop a viable and visible adaptive strategic management document that will promote the above elements if the organisation is to survive and meet the demands of South African consumers in term of electricity supply.

The third hypothesis deals with the analysis of the relationship between minimizing knowledge management challenges and organizational performance.

Hypothesis 3

H0: There is no positive relationship between minimizing knowledge management challenges and organizational performance

H1: There is a positive relationship between minimizing knowledge management challenges and organizational performances.

\begin{tabular}{|c|c|c|c|}
\hline \multicolumn{4}{|l|}{ Nature of Response } \\
\hline Respondents & $\begin{array}{l}\text { Yes, there is a relationship } \\
\text { between minimizing knowledge } \\
\text { management challenges and } \\
\text { organizational performance }\end{array}$ & $\begin{array}{l}\text { No, there is no relationship between } \\
\text { minimizing knowledge } \\
\text { management challenges and } \\
\text { organizational performance }\end{array}$ & Total \\
\hline Finance Department & $\begin{array}{l}23 \\
(20.5)\end{array}$ & $\begin{array}{l}02 \\
(4.5)\end{array}$ & 25 \\
\hline $\begin{array}{l}\text { Human Resource } \\
\text { Department }\end{array}$ & $\begin{array}{l}20 \\
(20.5)\end{array}$ & $\begin{array}{l}05 \\
(4.5)\end{array}$ & 25 \\
\hline Production Department & $\begin{array}{l}18 \\
(20.5)\end{array}$ & $\begin{array}{l}07 \\
(4.5)\end{array}$ & 25 \\
\hline Marketing Department & $\begin{array}{l}19 \\
(20.5)\end{array}$ & $\begin{array}{l}06 \\
(4.5)\end{array}$ & \\
\hline $\begin{array}{l}\text { Members of KM } \\
\text { practitioners }\end{array}$ & $\begin{array}{l}18 \\
(16.4)\end{array}$ & $\begin{array}{l}02 \\
(3.6)\end{array}$ & 20 \\
\hline $\begin{array}{l}\text { Academic Experts on } \\
\text { knowledge Management }\end{array}$ & $\begin{array}{l}17 \\
(16.4)\end{array}$ & $\begin{array}{l}03 \\
(3.6)\end{array}$ & 20 \\
\hline Total & 115 & 25 & 140 \\
\hline
\end{tabular}

Observed $\times 2=7.57$

$$
\mathrm{Df}=5
$$

Critical value at 0.95 level of significance $=1.145$ since the observed $\times 2$ is greater than the critical value, we reject the Ho hypothesis and accept the H1. This confirms that there is a positive relationship between minimizing knowledge management challenges and organizational performance.

To find out if there is a strong relationship, we used the pearsons contingency coefficient (C)

www.jbrmr.com A Journal of the Academy of Business and Retail Management (ABRM) 
$\mathrm{C}=\sqrt[X^{2}]{x^{2}+\mathrm{N}} \quad \mathrm{C}=0.23$

Since " $C$ " is not negative, this shows that the relationship is strong and not weak.

This finding confirms that there is a need for ESKOM to minimize knowledge management challenges facing the organization if it is to improve its performance. First, ESKOM must identify these challenges both in the short and long run and then find a mechanism on how to minimize these challenges.

Past studies on knowledge management have highlighted that the commonest challenges are following - organizational structure, culture, processes and system (Snowdem: 2003).

Organization structure in terms of the hierarchy and bureaucratic process hinders to a great extent knowledge sharing and utilization. The structure imposes limits to learning, generation of new knowledge, and knowledge dissemination. Unfortunately, these challenges will not be discussed here because it is not the focus of this research. However, the above issues need further investigation in respect of Eskom.

From the results of the research findings discussed above, we now developed a conceptual framework in Fig 2 below. For Eskom to improve its performance, there is an urgent need to consider this conceptual framework below.

Fig 2: Developed Conceptual Framework For ESKOM

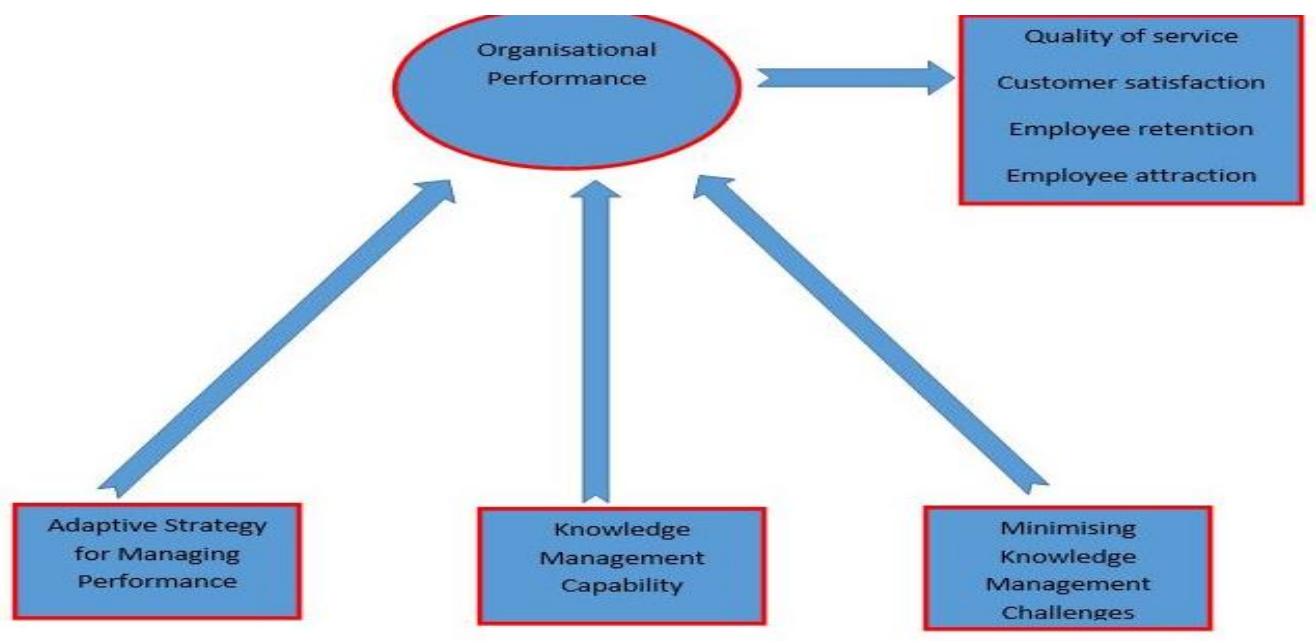

The above - developed conceptual framework illustrates the possible areas that ESKOM must pay attention to it if it is to increase its organizational performance. The adaptive strategy will allow for easy integration of various specialized knowledge within the organization through a set of process for capturing, integrating and applying knowledge. The main aim of this adaptive strategy is to foster innovation, creativity and better performance for ESKOM. The knowledge management capability will help ESKOM to further increase knowledge acquisition, refinement of knowledge including creating new knowledge which can easily lead to innovation.

Minimizing knowledge management challenges which includes inappropriate organizational hierarchy and culture, bureaucratic processes and the absence of a working definition of knowledge will greatly improve the performance of the organization. ESKOM management needs to pay attention to the above issues to increase the generation of new knowledge, knowledge dissemination and therefore promote the spirit of creativity and innovation, thus, increase ESKOM performance. 


\section{Conclusion and Recommendations}

From the above discussion, there is an urgent need for ESKOM to consider implementing the developed conceptual framework in this research by paying immediate attention to adaptive strategy for managing knowledge, knowledge management capability and how best to minimize the current challenges affecting knowledge management within its organization. In the same vein, ESKOM must align the recommended adaptive strategy for managing knowledge with the main strategic document of the organization where it spelt out its goals and objectives to be achieved by the organization which again is based on the mission and vision of ESKOM.

Furthermore, the issue of knowledge management capability and minimising knowledge management challenges must be included as part of the main objectives to be achieved in ESKOM main strategic document.

By paying serious attention to the area of adaptive strategy for managing knowledge, knowledge management capability and minimizing knowledge management challenges, this will increase the knowledge ESKOM needs to increase its organizational performance. However, a further research is needed to identify and explain in detail the nature of the current challenges facing knowledge management at ESKOM and in the same vein recommend measures that can be used to minimize these challenges

\section{References}

Alavi, M. \& Leidner, D. (2001). Review: knowledge management and knowledge management systems: conceptual foundations and research issues. MIS Quarterly, 25 (1), pp. 107-36.

Baskerville R. \& Dulipoci, A. (2006). The theoretical foundation of knowledge management. Knowledge Management Research and Practice, 4, pp.83-105.

Brooking, A. (1996). The management of Intellectual Capital. Journal of Long-Range Planning, 30(3), pp.364-365.

Buckman, R.H (1998). Knowledge sharing at Buckman Labs. Journal of business Strategy 19(1), pp.1-5.

Brown, S.L. et.al (1997). The art of continuous change: linking complexity theory and time paced evolution in relentlessly shifting organizations. Administrative Science Quarterly, 42 (I), pp. 1-34.

Cepeda, G. \& Vera, D. (2007). Dynamic capabilities and operational capabilities: a knowledge management perspective. Journal of Business Research, 60 (5), pp. $426-437$.

Choi, Y.R. \& Shepherd, D.A (2004). Entrepreneur's decisions to exploit opportunities. Journal of Management,30 (3), pp.377-95.

Chung, R.G. \& Lo, C.L. (2007). The relationship between leadership behaviour and organizational performance in non-profit organizations, using social welfare charity foundations as an example. Journal of America Academy of Business, of Business, Cambridge, 12 (I), pp. 83-7.

Davenport, et.al. (1998). Successful Knowledge Management Projects. Sloan Management Review, 39 (2), pp. 43-57.

Darroch, J. (2003). Developing a measure of knowledge management behaviors and practices. Journal of Knowledge Management, 7(5), pp41-54.

De Jarnett L. (1996). Knowledge the latest thing: information strategy. The Executives Journal 12 (2), pp3-5.

Earl, M. (2001). Knowledge Management Strategies: toward a taxonomy. Journal of Management Studies, 18 (1), pp. 2946.

EL-Korany A. (2007). A Knowledge Management application in enterprises. International Journal of Management and Enterprise Development, 4 (6), pp693-702.

Gavin, A.D. (1993). Building a Learning organization. Harvard Business Review, 74(4), pp.78-85.

Gold, A.H. et.al (2001). Knowledge Management: an organizational capabilities perspective. Journal of Management Information Systems, 18 (1), pp. 185-214.

Gold, A.H., Malhotra, A. \& Segars, A.H. (2001). Knowledge Management: an organizational capabilities perspective. Journal of Management Information Systems, 18 (1), pp85-214.

Grant, R.M. (1996). Toward a Knowledge - based theory of the firm. Strategic Management Journal, 17 pp.109-22.

Green, K.W. \& Inman, R.A. (2007). The impact of JIT-II-selling on organizational performance. Industrial Management and Data Systems, 107 (7) pp. 1018-35.

Gurteen D. (1998). Knowledge, creativity and innovation. Journal of Knowledge Management, 2(1) pp5-13.

Hansen, M.T. et. al (1999). What's your Strategy for managing knowledge? Harvard Business Review, 77 (2), p.106

Hansen, M.T. et-al (1999). What's your strategy for managing knowledge? Harvard Business Review, 77 (2), pp.106-16.

Hansen M.T, Nohria N, Tierney T. (1999). What's your strategy for managing knowledge? Harvard Business Review, March-April. 
Hsu, R-C; et.al (2007). Factors affecting knowledge management adoption of Taiwan small and medium-sized enterprises. International Journal of Management and Enterprise Development, 4(1), pp.88-115.

Huang, K.T. (1998). Capitalizing on intellectual assets. IBM Systems Journal, 37 (4), p.570

Kim, L. (1997). The dynamics of Samsung's technological learning in semiconductors. California Management Review, 39(3), pp. 86-100

Kim, Y.G. et.al. (2003). Knowledge Strategy Planning: Methodology and case. Expert Systems with Applications,24 (3), pp295-307.

Knupfer, N.N. \& McLellan, H. (2017). Descriptive research methodologies. Handbook of research for educational communications and technology.

Kurtz, C.F. \& Snowden, D.J. (2003). The new dynamics of Strategy: sense-making in a complex and complicated world. IBM Systems Journal, 42(3) pp. 462-83.

Marquardt, M.J. (1996). Building the Learning Organization. McGraw - Hill, New York, NY.

Massey et.al (2002). Knowledge management in pursuit of performance: Insights from Nortel Networks. MIS Quarterly, 26 (3) pp.269-89

Marshall C, Prusak L \& Shpilberg D. (1994). Financial risk and need for superior knowledge management. California Management Review 38(3), pp.70-107.

Mayo A. (1998). Memory bankers. People Management 4(2), 34-38

McElroy, M; (2003). The Knowledge Management: Complexity, Learning, and Sustainable Innovation KMCI Press, Boston, MA

Mei, et.al (2004). Formulating a communication strategy for effective knowledge sharing Journal of information science, 30 (1) pp.12-22

Nonaka, I. et.al (1995). The knowledge- Creating Company: How Japanese Companies Create the Dynamics of Innovation, Oxford University Press, New York, NY.

Nonaka, J. et.al. (2000). ECI, ba and leadership: a unified model of dynamic knowledge creation. Long Range Planning,33 (1) pp. 5-34

Peters T. (1992). Liberation Management Pan Books. New York, NY

Phusavat, K \& Kess, P. (2008). Roadmap for Knowledge sharing and transfer: sustaining outsourcing relationships. International Journal of Innovation and Learning, 5 (5).

Pillania. R.K. (2009). Demystifying Knowledge Management. Business Strategy Series,10 (2).

Punch, K.F. (2013). Introduction to social research: Quantitative and qualitative approaches. Sage.

Quin et.al (1996). Managing professional intellect: making the most of the best. Harvard Business Review, 74 (2), pp. 7181

Schultze, U (2000) A confessional account of an ethnography about knowledge work. MIS Quarterly, 24 (I), pp. 3-41

Scott, J.E. (2000). Facilitating interorganizational learning with information technology. Journal of Management Information Systems, 7 (2), pp 81-113.

Slater D. (1998). Storing the mind, minding the store. C10 11(9) pp. 46-51

Sherif, K. (2006). An adaptive Strategy for Managing Knowledge in organizations. Journal of Knowledge Management, 10 (4), pp. $72-80$

Struwig, F.W \& Stead, G.B. (2001). Planning, Designing and Reporting Research. Pub. Pearson Education, South Africa, Cape Town.

Sveiby, K.E (2001a). A knowledge-based theory of the firm to guide in strategy formulation. Journal of Intellectual Capital 2(4) pp. 344-358

Sveiby K.E. (2005). The new organisational wealth: managing and measuring knowledge-based assets, foreword to new Korean. edition. Available at http://www.sveiby.com/articles/koreanewsframeword.htm [20th May 2018]

Tanriverdi, H. (2005). Information technology relatedness, knowledge management capability, and performance of multibusiness firms. MIS Quarterly,29 (2), pp.311-34.

Teece, D.J. (2005). strategies for Managing Knowledge Assets: the role of firm structure and industrial context. Long Range Planning 33(1), pp. 35-54.

Tippins, M.J. \& Sohi, R.S (2003). Its competency and firm performance: ARE organizational learning a missing link. Strategic Management Journal, 24, pp.745-61.

Tiwana, A. (2002). The Knowledge Management Toolkit: Practical Techniques for Building a Knowledge Management, Prentice-Hall, Upper Saddle River, NJ.

Toudoir P.P. (1995). The Professional Knowledge Economy. Kluwer Academic Publishers, Dordrecht.

Tsoukas H, Vladimirou E. (2001). What is organizational knowledge. Journal of Management Studies 38(7) pp973-993.

Wickramasinghe, N. (2007). Fostering Knowlegde assets in healthcare with the KMI model. International Journal of Management and Enterprise Development, 4 (1) pp.52-65. 
Wiig K.M. (1997a). Integrating Intellectual Capital and Knowledge Management. Long Range Planning 30(3), pp. 399405.

Zack, M.H. (1999). Managing codified knowledge.

Sloan Management Review, 40 (4) pp. 45-58 